University of South Florida

DIGITAL COMMONS

Digital Commons @ University of

@ UNIVERSITY OF SOUTH FLORIDA

South Florida

School of Geosciences Faculty and Staff

Publications

School of Geosciences

$12-2015$

\title{
Fire and Flood Expand the Floodplain Shifting Habitat Mosaic Concept
}

\author{
W. J. Kleindl \\ University of Montana \\ Mark C. Rains \\ Univeristy of South Florida, mrains@usf.edu
}

\author{
L. A. Marshall \\ Montana State University \\ F. R. Hauer \\ University of Montana
}

Follow this and additional works at: https://digitalcommons.usf.edu/geo_facpub

Part of the Earth Sciences Commons

\section{Scholar Commons Citation}

Kleindl, W. J.; Rains, Mark C.; Marshall, L. A.; and Hauer, F. R., "Fire and Flood Expand the Floodplain Shifting Habitat Mosaic Concept" (2015). School of Geosciences Faculty and Staff Publications. 1223.

https://digitalcommons.usf.edu/geo_facpub/1223

This Article is brought to you for free and open access by the School of Geosciences at Digital Commons @ University of South Florida. It has been accepted for inclusion in School of Geosciences Faculty and Staff Publications by an authorized administrator of Digital Commons @ University of South Florida. For more information, please contact digitalcommons@usf.edu. 


\title{
Fire and flood expand the floodplain shifting habitat mosaic concept
}

\author{
W. J. Kleindl ${ }^{1,2,6}$, M. C. Rains ${ }^{3,7}$, L. A. Marshall ${ }^{4,5,8}$, and F. R. Hauer ${ }^{1,2,9}$ \\ ${ }^{1}$ Montana Institute on Ecosystems, University of Montana, Missoula, Montana 59812 USA \\ ${ }^{2}$ Flathead Lake Biological Station, University of Montana, Polson, Montana 59860 USA \\ ${ }^{3}$ School of Geosciences, University of South Florida, Tampa, Florida 33620 USA \\ ${ }^{4}$ Department of Land Resources and Environmental Sciences, Montana State University, Bozeman, Montana 59717 USA \\ ${ }^{5}$ School of Civil and Environmental Engineering, University of New South Wales, Sydney, New South Wales 2052 Australia
}

\begin{abstract}
The floodplain shifting habitat mosaic concept suggests that habitat patch dynamics are influenced by hydrologic disturbances driven by flood pulses of sufficient power to initiate incipient motion of the substratum and maintain cut-and-fill alluviation of the channel and banks. However, floodplain habitat mosaics are subject to other important landscape-scale disturbance regimes. In the Rocky Mountains of the USA and Canada, fire also affects floodplain habitat patch composition. The floodplain exists at the intersection of disturbance regimes that shape the riverscape and those that shape the landscape. We extended the shifting habitat mosaic concept by examining the effects of multiple disturbance elements on habitat patch composition across the aquaticterrestrial ecotone of the North Fork of the Flathead River, a free-flowing river in southeastern British Columbia, Canada, and northwestern Montana, USA. We used remotely sensed imagery, meteorological records, empirical and modeled rainfall-runoff data, extent and frequency of past wildfires, and anthropogenic landuse data for 1991-2013 to examine the relationships among hydrology, fire, landuse, geomorphic position, and floodplain habitat patch dynamics. Exploratory path analysis revealed that fire had the strongest total effect and stream power and geomorphic position had moderate total effects on the variability of floodplain habitat patch composition along the North Fork. These 3 factors explained 13 to 26\% of the variance in floodplain habitat patch composition between study reaches across all years. We used graphical analysis to examine the locations and intensity of disturbance and recovery pathways across floodplain transition zones throughout the study period. Our results support the hypothesis that hydrologic and fire disturbances and recovery pathways maintain the shifting habitat mosaic across the floodplains of this river system.
\end{abstract}

Key words: floodplain habitat, path analysis, mantel, alluvial graphs, network theory, assessment, remote sensing, ecosystem dynamics

Alluvial floodplains are among the most productive and diverse ecosystems and globally provide a rich array of ecological goods and services, but increasing exposure to human and climate-change stressors has made them one of the most threatened of ecosystems (Tockner and Stanford 2002, Tockner et al. 2010). Increasing threats to river ecosystem integrity create a pressing need for resource managers to develop innovative tools to monitor, assess, and manage alluvial floodplains in a changing world. However, many questions need to be addressed concerning potential constraints as these tools develop. Chief among these is: how can we assess whether an alluvial floodplain is changing as a response to natural variability, climate change, or human landuse disturbances, either individually or in combination? The answer requires a better understanding of the natural variability of alluvial systems.

Flooding and associated fluvial and geomorphic responses shape and maintain spatial and temporal heterogeneity of floodplain surfaces and plant communities that occupy them (Tockner et al. 2000, Stanford et al. 2005, Mouw et al. 2009). On large rivers, flooding events drive channel avulsion and cut-and-fill alluviation, which in turn create a mosaic of open water, cobble, and vegetation patches composed of various successional chronosequences (Mouw et al. 2009). The changes of these habitat patches in space and time, in accordance with flooding frequency

E-mail addresses: ${ }^{6}$ bill@naiadllc.com; ${ }^{7}$ mrains@usf.edu; ${ }^{8}$ lucy.marshall@unsw.edu.au; ${ }^{9}$ ric.hauer@flbs.umt.edu

DOI: 10.1086/684016. Received 4 November 2014; Accepted 6 May 2015; Published online 23 September 2015.

Freshwater Science. 2015. 34(4):1366-1382. ๑ 2015 by The Society for Freshwater Science. 
and magnitude under a natural hydrologic regime, are welldocumented in previous studies, the authors of which have proposed and refined the shifting habitat mosaic concept (e.g., Arscott et al. 2002, van der Nat et al. 2003, Stanford et al. 2005, Latterell et al. 2006, Whited et al. 2007, Mouw et al. 2013). However, riverscapes are a subset of larger landscapes and, thus, are subject to additional disturbances that act at different spatial and temporal scales (Ward 1998, Ward et al. 2002a, Wiens 2002, Allan 2004). Fire plays a critical role in shaping forests of western North America (Arno 1980, Keane et al. 2002), including floodplain forests (Dwire and Kauffman 2003, Pettit and Naiman 2007, Poff et al. 2011), but fire has been largely ignored in studies of the floodplain shifting habitat mosaic. Therefore, as a step toward understanding natural variability of alluvial floodplains in western North America, we need to understand the combined effects of flooding and fire on changes in habitat patch composition.

The hydrodynamics of floodplains are influenced by flood and flow pulses (Junk et al. 1989, Tockner et al. 2000, Lorang and Hauer 2006), bank storage dynamics where surface- and groundwater exchange occur between channels and underlying or adjacent deposits (Cooper and Rorabaugh 1963, Intaraprasong and Zhan 2009), and perirheic flows where river water interacts with regional or local waters from upslope surface- or groundwater sources (Mertes 1997, McGlynn and McDonnell 2003). High-energy flow pulses act at annual or sub-annual scales as the channel expands and contracts within the bankfull boundaries creating in-channel and near-channel erosional and depositional features (Tockner et al. 2000, Tockner and Stanford 2002, Lorang and Hauer 2006). Beyond the banks, high-energy erosive flood pulses, which can result in channel avulsion and cut-and-fill alluviation, occur at annual and supra-annual scales (Ward et al. 2002b, Hauer and Lorang 2004, Slingerland and Smith 2004, Stanford et al. 2005). The flood's erosive energy dissipates as it extends beyond the bankfull perimeter and disperses across the expansive surface of the floodplain (Ward et al. 2002b), further creating backwater flooding or inundation as it interacts with rising hyporheic or perirheic waters (Mertes 1997, McGlynn and McDonnell 2003). The varied hydrodynamics result in multiple and complex inundation and recession pathways (Hughes 1980, Lewin and Hughes 1980), with diverse and sometimes abrupt energy gradients across floodplain surfaces (Tockner et al. 2000, Tockner and Stanford 2002, Lorang and Hauer 2003). The hydrodynamics interact with existing vegetation and topography to drive erosion and depositional processes (Camporeale et al. 2013, Gurnell 2014). These interactions determine the formation and maintenance of floodplain geomorphic features (Miall 1985, Stanford et al. 2005) and the degree of surface and subsurface connectivity across the river-floodplain transition (Tockner et al. 2000, Brunke et al. 2003). In high-order, cobble- and gravel- dominated alluvial systems of western North America, these processes create diverse depositional floodplains, some $>1 \mathrm{~km}$ in width.

Stanford et al. (2005) described 3 linked series (catenae) of structural habitat features on expansive floodplain depositional surfaces. From the river to the hillslope, these increasingly terrestrial habitat elements consist of the parafluvial catena that lies below bankfull, where erosional and depositional features are maintained by flow pulses and are dominated by open water and cobble bars, with early successional seedlings and herbaceous cover at its fringe. The 2 orthofluvial catenae are active and passive accretion areas. The active accretion areas, frequently reworked by high-energy erosive flood pulse events, exhibit thinly developed soils with higher hyporheic waters and predominantly deciduous, age-segregated, riparian woody vegetation. The passive accretion areas occur on floodplain benches that are rarely flooded; these have deeper organic soils with decreased access to ground waters and are generally composed of mature deciduous or coniferous late successional (gallery) riparian forest. Beyond these areas are terraces that are no longer inundated by floods and hill slopes that may be dominated by terrestrial vegetation, yet may still be influenced by the microclimate of the floodplain (Naiman et al. 1993, Naiman and Décamps 1997, Stanford et al. 2005). Within these catenae, floodplain hydrodynamic and biogeomorphic processes also create conditions that enhance or discourage fire through a combination of fuel abundance, species composition, microclimate, and fuel and soil moisture gradients (Dwire and Kauffman 2003, Pettit and Naiman 2007, Poff et al. 2011).

Fires on floodplains operate at different spatial and temporal scales than hydrologic disturbances. Fires are influenced by top-down and bottom-up biogeoclimatic forces, where the extent, severity, and return intervals of the fires are controlled by interactions of climate, topography, aspect, fuel load and combustibility, and disturbance history (Turner and Romme 1994, Rollins et al. 2002, Perry et al. 2011). These elements interact to determine patterns of tree mortality and survivorship from fires (Arno et al. 2000, Rollins et al. 2002). Mixed-severity fires are poorly understood (Perry et al. 2011), but they have influenced the composition of major forest types in the Rocky Mountains (Schoennagel et al. 2004). Mortality patterns caused by mixed-severity fire regimes result in diverse forest communities composed of different species and age-class mosaics, with patch sizes ranging from a few square meters to tens or hundreds of hectares (Perry et al. 2011). Given the return intervals, these patches shift spatially and temporally, creating a landscape-scale terrestrial shifting habitat mosaic as previously described by Bormann and Likens (1979). On the expansive depositional floodplains of high-order, cobble-dominated rivers, the riparian forests are characterized by transitions from the 
river's edge to terrestrial ecosystems and are made up of biogeoclimatic gradients that differ from the surrounding uplands (Pettit and Naiman 2007). Fires in riparian forests vary proportionally with the severity and extent of burning within the catchment (Pettit and Naiman 2007), but the interaction with the river's hydrodynamics creates unique biogeomorphic attributes that influence fire severity, extent, and pattern within the floodplain and recovery from fire (Dwire and Kauffman 2003, Jackson and Sullivan 2009).

We explored the dominant disturbance factors that influence floodplain habitat patch composition of the North Fork of the Flathead River, a large, free-flowing CanadaUSA transboundary Rocky Mountain river. We observed $22 \mathrm{y}$ of disturbance and recovery pathways to expand the floodplain shifting habitat mosaic concept (Stanford et al. 2005) from one singularly driven by major hydrologic events to one that blends the effects of riverscape and landscape disturbance regimes on floodplain habitat patch dynamics. We hypothesize that the habitat patches within each floodplain catena shift in space and time in response to complex interactions of flood and fire disturbance and subsequent recovery vectors. Collectively, these disturbance/recovery vectors create a network of shifting habitat elements that define contemporary system variability. We addressed 3 research questions to examine the influence of natural disturbance and recovery on floodplain habitat mosaic distribution and changes: 1) To what extent do fire, flood, and geomorphic position explain floodplain habitat patch composition at 6 points in time? 2) What are the disturbance and recovery pathways that best describe shifts in floodplain habitat patch composition over the study period? 3) Where on the floodplain do these disturbance and recovery pathways occur across the period of study?

\section{METHODS}

\section{Study area}

The North Fork of the Flathead River is a cobbledominated, free-flowing, snowmelt system in Southeastern British Columbia, Canada, and northwestern Montana, USA (Fig. 1). This transboundary watershed has a total drainage area of $4057 \mathrm{~km}^{2}$ in the first valley west of the Continental Divide spanning the Canada-USA boundary. In British Columbia and Montana, the lands are predominantly public forest, regional and national parks, and, to a lesser extent, private holdings. In Montana, the North Fork channel defines the western boundary of Glacier National Park. Mean annual precipitation along the valley floor is $560 \mathrm{~mm}$, which falls predominantly as snow, and mean annual temperature is $4.0^{\circ} \mathrm{C}$, with monthly averages ranging from $-14.1^{\circ} \mathrm{C}$ in January to $26.6^{\circ} \mathrm{C}$ in July (WRCC 2014). The highest elevation in this montane watershed is $3078 \mathrm{~m}$ asl at Kintla Peak in Glacier National Park. The river elevation ranges from $1543 \mathrm{~m}$ asl to $948 \mathrm{~m}$

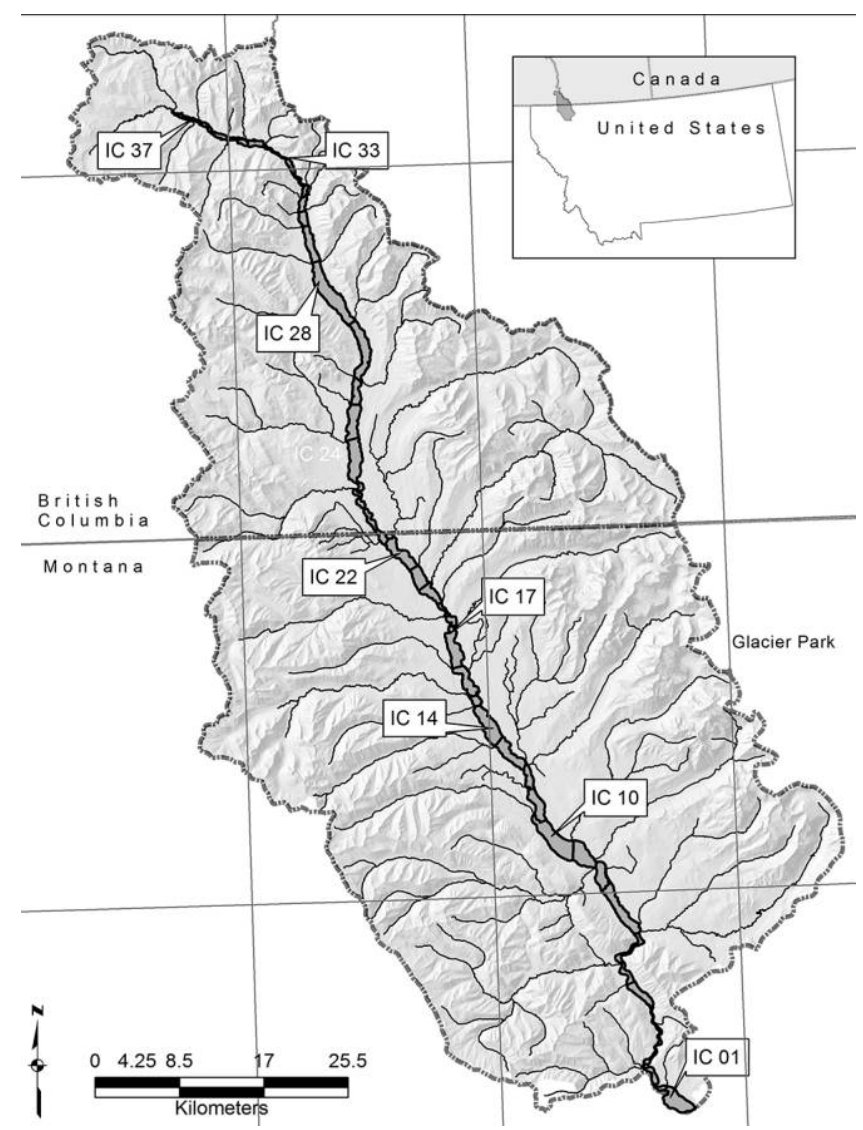

Figure 1. Location of the North Fork of the Flathead River, major contributing streams, delineation of the North Fork floodplain, and interconfluence reaches (ICs, with 8 of 37 labeled).

asl with a mean slope of $0.4 \%$. At the US Geological Survey (USGS) gauge station near the bottom of the study area (no. 2355500), the North Fork experienced a mean annual discharge during the time span of this study (1980-2013) of $83 \mathrm{~m}^{3} / \mathrm{s}$ and a maximum discharge of $1062 \mathrm{~m}^{3} / \mathrm{s}$ recorded on 8 June 1995. The greatest discharge for the period of record extending to 1911 was $1957 \mathrm{~m}^{3} / \mathrm{s}$ on 9 June 1964. The 2 -y flood return interval is $\sim 585 \mathrm{~m}^{3} / \mathrm{s}$, the 10 -y flood is $\sim 850 \mathrm{~m}^{3} / \mathrm{s}$, and the 50 -y flood is $\sim 1120 \mathrm{~m}^{3} / \mathrm{s}$ (Omang 1992).

The study area consisted of 10,165 ha of valley bottom floodplains along $160 \mathrm{~km}$ of river. Aerial imagery was used to conduct analysis of multiple floodplain reaches within the valley bottom. The upstream and downstream limits of these reaches were delineated at the confluences of the main stem and each major contributing stream. Major streams were defined as streams with a bed-andbank that was readily observed from available aerial imagery and were generally $3^{\text {rd }}$ or $4^{\text {th }}$ Strahler stream order. Several major contributing streams were nearly adjacent and were combined to result in 37 interconfluence (IC) reaches. The IC reaches are numbered from IC- 1 at the 
bottom of the watershed to IC-37 at the top of the watershed (Fig. 1). The IC reaches consisted of broad alluvial depositional areas typically associated with floodplain ecosystems and confined reaches with limited floodplains, which ranged from 53 to 812 ha in size. We mapped the spatial extent of the study area in ArcGIS (version 10.0; Environmental Systems Research Institute, Redlands, California) with the assistance of background imagery from the US Department of Agriculture National Agriculture Imagery Program (NAIP; USGS 2014) from year 2005. The map was subsequently overlain with an additional 30-m digital elevation map (USGS 2013), visual assistance from oblique views in Google Earth ${ }^{\circledR}$ 's 3-dimensional models (Google Earth 2013), and oblique imagery from aerial reconnaissance.

\section{Data collection}

We collected 4 types of data across the study period: 1) floodplain habitat cover types and anthropogenic land use, 2) major geomorphic catena within the floodplain, 3) burned area within the study area and period, and 4) daily stream power as a surrogate measure of the potential erosive force of flooding. The study period coincided with the rise of publicly available, large-scale data. These data were available at different time spans across the study period: cover types and geomorphic catena 1991-2013, burn area 1984-2013, and stream power 1980-2012. Unless otherwise stated, all data collection and subsequent analysis was organized in ArcGIS and R (version 3.1.1; R Project for Statistical Computing, Vienna, Austria).

Land-cover classification We used publicly available high-resolution imagery from 1991, 2003, 2005, 2009, 2011, and 2013 to classify floodplain habitat types within each interconfluence reach for each year of image data (Table S1). Aerial imagery for both Canada and the USA that include the entire length of the river was available for 2005 only. The USA reaches IC-1 to IC-22 had consistent imagery across all $6 \mathrm{y}$, covering $93 \mathrm{~km}$ of river and 6320 ha of floodplain. Site IC-22 begins at the confluence of Sage Creek and the North Fork, $1.2 \mathrm{~km}$ downstream of the Canadian border (Fig. 1). All imagery was georectified by the provider, and spatial accuracy was confirmed by comparing multiple points across all years. All points were within $5 \mathrm{~m}$ and most were within 2 to $3 \mathrm{~m}$ across the entire image series except one 2003 quad that required a $100-\mathrm{m}$ correction.

We used the generalized random tessellation stratified (GRTS) sampling function in the Spsurvey $\mathrm{R}$ package (Kincaid and Olsen 2013) to randomly select 100 unstratified sample points within each IC reach. These points remained fixed in space and were used to classify floodplain habitat types across each of the 6 sample years. Through previous studies (Hauer et al. 2002), aerial re- connaissance, and a single site visit, we defined 12 floodplain habitat types to be identified by aerial imagery ( $\mathrm{Ta}$ ble 1). We imported the sample points into ArcGIS and transformed them into cross-hatched circles with a 5-m diameter when the aerial image was visually examined under each point from a fixed scale of $1: 1500$. We assigned the dominant cover in the cross-hatched circle to 1 of the 12 floodplain habitat types (Table 1). The black-andwhite image from 1991 was taken in autumn and provided a clear distinction between deciduous and coniferous mature trees and informed sample points in stable patches in other years when the distinction was less clear. We iteratively refined the classification in 2013, when we verified 100 sample points stratified across all floodplain

Table 1. Floodplain habitat types of the North Fork of the Flathead River (modified from Hauer et al. 2002).

\begin{tabular}{|c|c|}
\hline $\begin{array}{l}\text { Floodplain } \\
\text { habitat types }\end{array}$ & Description \\
\hline 1 & Mature conifer \\
\hline 2 & Mature deciduous \\
\hline 3 & Immature deciduous $2-6 \mathrm{~m}$ in height \\
\hline 4 & $\begin{array}{l}\text { Cottonwood, willow, or alder seedlings and } \\
\text { early seral stages up to } 2 \mathrm{~m} \text { in height } \\
\text { interspersed with open cobble area }\end{array}$ \\
\hline 5 & $\begin{array}{l}\text { Filled or partially filled abandoned channel } \\
\text { dominated by mix of willows, alder, } \\
\text { shrubs, and interspersed herbaceous } \\
\text { cover and postfire herbaceous dominated } \\
\text { interspersion of fire-scarred snags or } \\
\text { fire-stressed trees }\end{array}$ \\
\hline 6 & $\begin{array}{l}\text { Herbaceous vegetation dominated bench, } \\
\text { with possible interspersions of an } \\
\text { occasional shrub. Includes post-fire } \\
\text { herbaceous dominated with interspersion } \\
\text { of fire-scarred snags or fire-stressed trees }\end{array}$ \\
\hline 7 & Exposed cobble river bed \\
\hline 8 & Main channel \\
\hline 9 & Off main channel surface water \\
\hline 10 & $\begin{array}{l}\text { Managed lands, including agriculture } \\
\text { meadows and plowed fields that are often } \\
\text { planted and hayed, fallow fields that are } \\
\text { proximal to Cover Type 11, and recently } \\
\text { logged lands and tree farms }\end{array}$ \\
\hline 11 & $\begin{array}{l}\text { Domestic or commercially developed lands, } \\
\text { including homes, buildings, gravel pits, } \\
\text { and transportation corridors }\end{array}$ \\
\hline 12 & $\begin{array}{l}\text { Early succession forest: immature woody } \\
\text { species predominantly composed of } \\
\text { conifer or shrubs } 2-6 \mathrm{~m} \text { in height and } \\
<10-\mathrm{cm} \text { diameter at breast height, } \\
\text { interspersed with fire-scarred snags }\end{array}$ \\
\hline
\end{tabular}


habitat types in the field, and either corrected errors for similar points across all years or refined floodplain habitat type definitions. We recorded these data as \% cover of each floodplain cover type $\times$ IC reach $\times$ year.

Floodplain geomorphic composition We coarsely classified geomorphic zones that delineate the lateral extent of the study area into structural catenae defined by Stanford et al. (2005): parafluvial areas, active accretion orthofluvial, and passive accretion orthofluvial (hereafter, the active channel, active floodplain, and passive floodplain, respectively). We excluded terraces that never flood from the study. We delineated each catena by digitizing polygons of aerial images with a minimum mapping unit of $\sim 25 \mathrm{~m}^{2}$ in ArcGIS for all years. We identified the polygons with the assistance of background imagery, visual assistance from oblique views within Google Earth's 3-D models (Google Earth 2013), oblique imagery from aerial reconnaissance, and multiple site visits. We calculated the relative ratios of aerial coverage of each catena for each IC reach for each year.

Burned area Maps of burned areas in the USA are provided by the Monitoring Trends in Burn Severity (MTBS) project, which maps fires in the USA with Landsat TM satellite imagery available from 1984-2012 (MTBS 2014). MTBS annually maps a large extent of the western USA with limited plot-based confirmation of burn severity within each fire polygon (MTBS 2014). As a result, uncertainties exist regarding specific locations of severity in each map. Therefore, we chose a discrete fire perimeter for subsequent effects analyses and relied on our sampled data to identify specific locations and disturbance responses from fires in our study period. Four very large fires crossed the USA portion of the floodplain in the study period: the 1988 Red Bench, 2001 Moose, and the 2003 Robert and Wedge Canyon Fires, whose burn perimeters enclosed $755,919,563$, and 265 ha in the study area, respectively. All fires in the Canadian portion of the floodplain occurred before 1940, allowing for sufficient recovery of the forest and, therefore, were not included in subsequent analysis (DataBC 2014).

Stream power To estimate stream power for each of the 37 IC reaches, we modeled a continuous daily hydrograph for the cumulative watershed area above each IC reach using the HBV-EC hydrologic model (Jost et al. 2012, Mahat and Anderson 2013). The model setup consisted of defining alpine and subalpine climatic zones above and below $1980 \mathrm{~m}$ elevation, respectively. The climatic zones were associated with climatic data and 4 landcover types (open, forest, glacier, and water), thereby creating a unique parameter set for each zone (Canadian
Hydraulics Centre 2010). Land cover was fixed across the modeling period for climatic zones, with open areas, lakes, and glaciers classified as such and the remaining area classified as forest. The required climate inputs were mean temperature and evaporation rate as monthly time steps, and mean temperature, rainfall, and snowfall as daily time steps for the simulated time period. We acquired the monthly evaporation rate from the closest pan evaporation data (WRCC 2013) and applied it to each zone. We obtained all daily meteorological inputs from DAYMET, a 1-km gridded metrological data set with daily data from 1980 to 2012 (Thornton et al. 2012). The required daily and monthly data were spatially averaged for each climate zone across each of the 37 cumulative subwatershed areas.

Our modeling strategy was first to develop and calibrate a hydrological model with a specific spatial structure and model parameter set for the entire North Fork watershed using daily discharge data from the USGS gauge station (no. 12355500). The initial model parameter set was from a calibrated HBV-EC hydrologic model from the nearby Mica Watershed (Jost et al. 2012), situated $\sim 150 \mathrm{~km}$ north of the North Fork Watershed. Model parameters were optimized through 10 iterations against increasing Nash-Sutcliffe (1970) efficiency objective function thresholds (0.2-0.6). Initial iterations consisted of $100 \mathrm{~K}$ model runs that decreased to $12 \mathrm{~K}$ as the model became more efficient. Ultimately, we used the Monte-Carlo Analysis Toolbox in MATLAB (version 8.1; Mathworks, Natick, Massachusetts; Wagener et al. 2001) to establish the top-10 optimal parameter sets. Next, these parameter sets were applied to the cumulative watershed above the British Columbia gauge station (no. 08NP001; Environment Canada 2013), situated on the North Fork at the USA/Canada border, for validation and final parameter set selection. We then used the final optimal parameter set to model discharges from 37 cumulative watershed areas upstream of each of the $37 \mathrm{IC}$ reaches to establish a continuous daily discharge for each reach. Stream power represents the potential amount of energy (in W) that a stream can exert on its bed and bank as a product of the water density $\left(1000 \mathrm{~kg} / \mathrm{m}^{3}\right)$, acceleration of gravity $(g=$ $\left.9.8 \mathrm{~m} / \mathrm{s}^{2}\right)$, slope of the reach $(\mathrm{m} / \mathrm{m})$, and discharge in that reach $\left(\mathrm{m}^{3} / \mathrm{s}\right)$ from the modeled results (Bull 1979). Collectively, these data provide daily stream power as a surrogate of the erosive power of peak flows for each IC reach from 1980 to 2012.

\section{Data analysis}

We chose 3 analytical approaches to answer our 3 research questions. First, we used an exploratory path analysis to examine the explanatory power of fire, flood, and geomorphic positions on floodplain habitat patch composition between IC reaches. Second, we used graphical in- 
terpretation of the data to inform and interpret disturbance and recovery within floodplain habitat patches as a network of shifting habitat elements through time. Third, we used the above approaches as aids to examine locations and types of transitions within floodplain habitat patches across the geomorphic catenae.

Mantel tests and exploratory path analysis We chose path analysis, an extension of multiple regression, to estimate the magnitude and strength of effects within the hypothesized causal system using quantitative correlational interrelationships (Stage et al. 2004). We used an exploratory approach to construct a new model that best explained the hypothesized causal patterns of our data (Grace et al. 2010). We derived the model's dependent variable from land-cover data. Floodplain habitat types 19 and 12 (Table 1) were considered native habitat cover, whereas floodplain habitat types 10-11 (agriculture and logging) were considered human land use and were assessed as potential explanatory variables. We created a Bray-Curtis similarity matrix based on the native habitat cover of each IC reach and used it as the response variable. Euclidian distance matrices obtained from potential explanatory variables were derived from MTSB burn data, modeled discharge data, measures of geomorphic composition, and other physical measures of each IC reach (Table 2). The Bray-Curtis and Euclidian distance matrices provided continuous data between 0-1.

We conducted Mantel tests (Mantel 1967) to compare the multivariate habitat patch similarity matrix directly with potential independent explanatory variables using the 2005 data set for the entire river (Legendre and Legendre 2012). Last, we used iterative Mantel tests to select a subset of environmental parameters that best correlated with the Bray-Curtis floodplain habitat patch similarity matrix across all sampled IC reaches (Sokal and Rohlf 1995, Strohbach et al. 2009). The iterative Mantel tests allowed us to refine our modeled system by selecting the best measures of environmental variables. It also alerted us to other potential explanatory variables that were significant and to remove or be aware of redundant or collinear variables.

Once we acquired a subset of environmental variables, we conducted partial Mantel tests to inform direction and significance of the paths in the model (Legendre and Legendre 2012). Partial Mantel tests estimate correlation strength between 2 distance matrices after the effect of $\geq 1$ matrices has been eliminated (Mantel 1967, Smouse et al. 1986). As in the Mantel test, significance was assessed by repeated permutations that provided a reference distribution for the computed statistic (Smouse et al. 1986). The final exploratory model was schematically represented in a path diagram. A direct relationship existed between all paired variables in our final path model. There-
Table 2. Potential explanatory variables, Mantel correlation coefficients $\left(r_{M}\right)$, and significance $(p)$ of the Euclidian distance matrices compared to the habitat composition Bray-Curtis similarity matrix for 1000 Mantel permutations with $\alpha=0.05$. Explanatory variables selected for path analysis are in bold.

\begin{tabular}{lcc}
\hline Potential explanatory variables & $r_{M}$ & $p$ \\
\hline Fire burn area & $\mathbf{0 . 4 5 5}$ & $\mathbf{0 . 0 0 1}$ \\
$\mathbf{7 5}^{\text {th }}$ percentile stream power & $\mathbf{0 . 2 2 2}$ & $\mathbf{0 . 0 0 2}$ \\
Mean stream power & 0.224 & 0.002 \\
Ratio of passive/total catenae & $\mathbf{0 . 2 8 7}$ & $\mathbf{0 . 0 0 7}$ \\
Sum of stream power & 0.186 & 0.007 \\
Ratio passive/active catenae & 0.275 & 0.008 \\
Log(mean power) & 0.172 & 0.019 \\
Slope & 0.134 & 0.028 \\
\% active catena & 0.118 & 0.052 \\
Log(passive catena) & 0.103 & 0.107 \\
Width & (2) & 0.128 \\
Spatial distance & 0.068 & 0.191 \\
Width & 0.048 & 0.203 \\
\% active channel catena & 0.054 & 0.296 \\
\% managed lands & 0.041 & 0.303 \\
\% exurban & 0.049 & 0.349 \\
Area & 0.023 & 0.511 \\
\hline
\end{tabular}

fore, the model was considered saturated, which precluded an overall test-of-fit (Castillo-Monroy et al. 2011).

We used simple Mantel correlation coefficients to calculate path coefficients, coefficients of determination, and remaining errors in the exploratory path analyses (Natel and Neumann 1992, Sokal and Rohlf 1995, Grace 2006). Path coefficients, analogous to regression weights or partial correlation coefficients, range from 0 to 1 and describe the strength of each pathway. The relative magnitudes of path coefficients tell us if our hypothesized causal relationship was supported by the data and provide a means to calculate direct, indirect, and total effects that each explanatory variable have on the response variable (CastilloMonroy et al. 2011). Mantel and partial Mantel tests were performed on all distance matrices with the vegan package in $\mathrm{R}$ (Oksanen et al. 2013), and all path statistics and direct, indirect, and total effects were calculated using the sem package in R (Fox et al. 2013).

Turnover Path analysis alone does not provide insight into the locations of floodplain habitat patches or degree of change in these patches across time. We examined turnover in habitat composition by conducting pairwise Mantel tests of the Bray-Curtis similarity habitat matrices made up of IC-1 through IC-22 across all years to assess degree of dissimilarity (i.e., turnover) of the floodplain habitat patch composition across the sampling pe- 
riod. With this method, Mantel correlations closer to 1 indicated that the floodplain habitat composition in year $x$ was similar to year $y$, and the closer the correlation was to 0 , the more dissimilar they were because of changes in composition. We then examined specific structural shifts by conducting graphical analyses.

Graphical analysis To examine all changes at IC-1 through IC-22 across this period, we developed a transition table between 1 sample year and the following sample year. These tables recorded habitat cover types that either remained static or shifted to a different type between the 2 sample years. The interannual transition tables were then displayed in the form of an alluvial diagram to visually examine the type and intensity of disturbance and recovery pathways that drive cover-type dynamics across the study period. Transitions were assigned to disturbance or recovery vectors based on observed changes in the years between aerial images. The alluvial graphical tool is currently in development in R (https://github.com/mbojan /alluvial). To examine where the drivers of turnover occurred on the riverscape graphically, we organized matrices of habitat cover according to geomorphic position across all years and assigned these transitions based on results from path analysis and the alluvial graph.

We also summarized the pathways in a final transition table across all 22 y (1991-2013) to examine 2 elements of change: 1) \% change by geomorphic catena, and 2) interrelated networks of habitat shift across time. Change associated with disturbance or recovery pathways across all years was graphed according to where the changes occurred on the floodplain geomorphic catena. A network graph also was created in which each cover type was considered a 'node' and the transitions between floodplain habitat types were considered 'edges' with arrows signifying the direction of the transitions and weights of the arrows representing numbers of transitions. Closely related transitions within the network were derived from a randomwalk algorithm (walktrap within iGraph in R; Pons and Latapy 2005). The factors found to be significant in the path analysis (hydrologic and fire disturbance) and the nonsignificant but important drivers implied in the alluvial graph (anthropogenic land use) informed assignment of drivers to shifting mosaics, the cover types they influenced, and the influence of human actions on cover-type transitions.

\section{RESULTS}

We hypothesized that floodplain habitat patch composition was a result of interactions of erosive flooding and fire influenced by the geomorphic makeup of the floodplain and that across multiple years, these interactions created a network of shifting habitat elements. Each ana- lytic approach informed the next. The path analysis provided a static assessment of the magnitude of the relationships between variables in our hypothesized causal model for each of the $6 \mathrm{y}$ analyzed. The path analysis alludes to either dynamics in explanatory variables or composition of the response variable, but does not directly address those dynamics. Turnover was assessed through simple Mantel tests that compared the Bray-Curtis similarity matrices of the floodplain habitat patch composition across all years in pairwise fashion. The longer the time was between study periods, the more dissimilar the river habitat became $\left(R^{2}=0.93, p<0.001\right)$, indicating turnover in the patch composition. Turnover was illustrated in an alluvial graph with disturbance and recovery transitions drivers informed by results of path analysis and observations from aerial assessment. Transitions assigned to each disturbance and recovery vector in the alluvial graphs also were examined across each floodplain geomorphic catena. These transitions, their environmental drivers, and their locations on the floodplain informed the final network graph.

\section{Mantel tests and path analysis}

To build our exploratory path model, we investigated the measures of fire, flood, and geomorphic position with the strongest relationship to floodplain habitat patch composition. We also assessed whether other less obvious potential explanatory variables existed within our data set. Using the 2005 whole-river data set (including the Canadian portion), we found 3 variables that provided highest correlations to floodplain habitat patch composition: \% IC reach that was burned (Fire: $r_{M}=0.46, p=0.001$ ), stream power calculated from the $75^{\text {th }}$ percentile of modeled discharge from the beginning of the modeling period (January 1980) to June of the sample year (StrPow: $r_{M}=0.22, p=$ 0.002 ), and the ratio of passive floodplain catena to the remaining valley bottom (GeoPos: $r_{M}=0.13, p=0.039$ ) (upper portion of Table 3). Several other attributes were statistically significant and had high Mantel correlations, but were either collinear with the above variables (e.g., slope) or redundant (e.g., stream power calculated from mean modeled discharge) and, thus, were eliminated from further analysis (Table 2). Correlations that lacked statistical significance also were eliminated (Table 2). The partial Mantel $\left(r_{p M}\right)$ tests revealed strong relationships between stream power and burned area against floodplain habitat patch composition after removing effects of other explanatory variables. However, the relationship between geomorphic position and habitat patch composition was weak when the effects of stream power and fire were removed (lower portion of Table 3). These partial relationships were used to build the final exploratory path model from the 2005 whole-river data set (Fig. 2). 
Table 3. Pearson correlation results for simple $\left(r_{M}\right)$ and partial $\left(r_{p M}\right)$ Mantel tests for 3 spatial factors vs habitat cover for the 2005 whole-river data set. Correlations were tested between stream power (StrPow), fire (Fire), geomorphic position (GeoPos), and habitat composition (Hab). All partial Mantel tests that remain significant at the Bonferroni-corrected level $(0.05 / 3=0.0167)$ for an overall significance of $p<0.05$ (Miller 1966), after removing a particular (R) spatial environmental factor effect, are marked by an asterisk in the lower section.

\begin{tabular}{|c|c|c|c|c|c|c|}
\hline Mantel test & StrPow $\times$ Hab & Fire $\times$ Hab & GeoPos $\times$ Hab & StrPow $\times$ Fire & GeoPos $\times$ StrPow & GeoPos $\times$ Fire \\
\hline Simple & $\begin{aligned} r_{M} & =0.22 \\
p & =0.002\end{aligned}$ & $\begin{aligned} r_{M} & =0.46 \\
p & =0.001\end{aligned}$ & $\begin{aligned} r_{M} & =0.13 \\
p & =0.039\end{aligned}$ & $\begin{aligned} r_{M} & =0.27 \\
p & =0.001\end{aligned}$ & $\begin{aligned} r_{M} & =0.06 \\
p & =0.117\end{aligned}$ & $\begin{aligned} r_{M} & =-0.01 \\
p & =0.486\end{aligned}$ \\
\hline \multicolumn{7}{|l|}{ Partial } \\
\hline StrPow (R) & - & $r_{p M}=0.40 *$ & $r_{p M}=0.11$ & - & - & $r_{p M}=-0.02$ \\
\hline Fire (R) & $r_{p M}=0.15^{*}$ & - & $r_{p M}=0.14$ & - & $r_{p M}=0.07$ & - \\
\hline GeoPos (R) & $r_{p M}=0.24 *$ & $r_{p M}=0.45^{*}$ & - & $r_{p M}=0.27^{*}$ & - & - \\
\hline
\end{tabular}

The path model explained $24 \%$ of the variance in floodplain habitat patch composition for the 2005 whole-river data set (2005.37), and 13 to $26 \%$ of the variance in floodplain habitat patch composition across all years (Table 4). Fire (path coefficient $p_{43}$ ) had the greatest effect on floodplain habitat patch composition, with coefficients ranging from 0.32 to 0.45 across all years (Table 4). The total effect of geomorphic composition and stream power on floodplain habitat patch composition varied widely across sample years, ranging from 0.07 to 0.23 and 0.01 to 0.25 , respectively (Table 5).

\section{Type and location of transitions}

The path analyses support fire and hydrodynamics as important disturbance drivers in the system. However, 2200 cover-type transitions occurring over 22 y of observation of IC- 1 through IC-22 reaches also showed recovery as an important transition element, and to a lesser extent, anthropogenic disturbance $(11,000$ points that remained static; Fig. 3). Transition types were assigned to disturbance and recovery vectors in an alluvial graph. For instance, between 1991 and 2003, many points classified as mature conifer (habitat type 1, Table 1) from aerial imagery in 1991 were burned and transitioned to herbaceous vegetation with snags and fallen timber (habitat type 6) in the 2003 classification. In the alluvial graph, transitions between habitat types 1 and 6 were attributed to fire-driven disturbance (orange in Fig. 3). We used the same approach to assign the remaining flooding, anthropogenic, and succession pathways.

The path analyses support geomorphic position as an important disturbance driver. The 2200 transitions across the study period were associated with geomorphic catena (Fig. 4). The habitat transitions associated with fire disturbance occurred nearly equally on the passive and active floodplain, whereas disturbance associated with hydrodynamics dominated the active channel, and to a lesser extent, latterly across the floodplain (Fig. 4). Logging and exurban development predominantly appeared in the pas- sive orthofluvial floodplain. Recovery was associated with hydrologic disturbance-driven transitions in the active channel and with fire and logging in the passive floodplain.

\section{Shifting habitat mosaic}

Transitions across all 22 y were combined into a single summary table (Table 6) and viewed graphically as a network (Fig. 5). The random-walk algorithm revealed that 3 optimal disturbance/recovery communities were established (modularity $=0.419$; colored clouds in Fig. 5). Informed by the path analysis, the alluvial graph, and locations patch change associated with disturbance and recovery, we assigned transitions within each color cloud

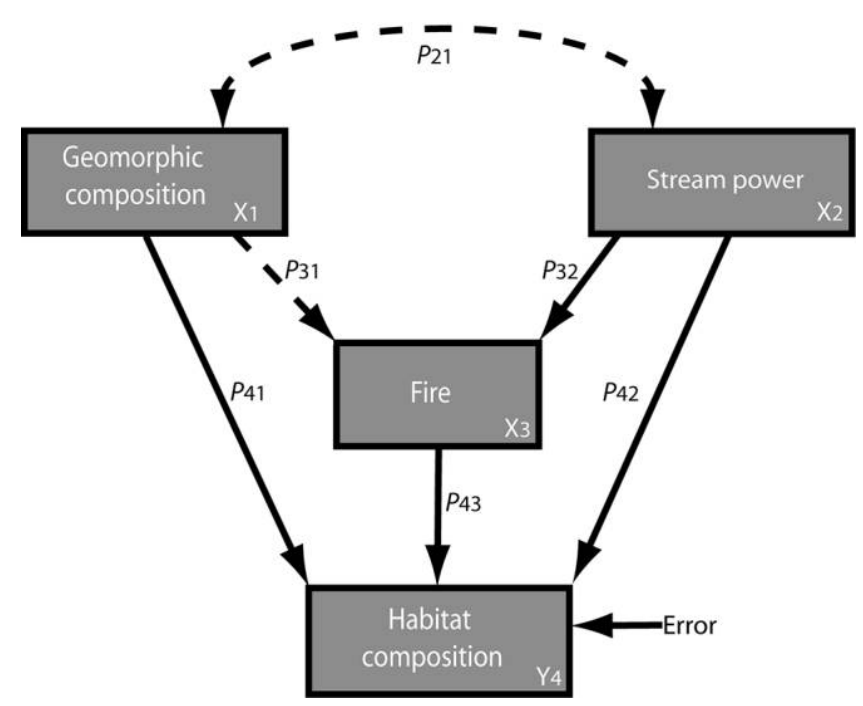

Figure 2. Final exploratory path analysis depicting the relationships between explanatory variables $\mathrm{X} 1-\mathrm{X} 3$ (geomorphic composition, stream power, and fire) and the response variable Y4 (floodplain habitat patch composition). Arrows indicate direction of influence, with the associated path identification number. Double-sided arched line indicates recognized collinearity, and solid lines indicate statistically significant relationships. 
Table 4. Path coefficients, total error, and coefficient of determination for all sample years (sites IC-1 through IC-22), and the 2005 whole-river data set which extends to IC-37 (2005.37). Path coefficient labels (e.g., $p_{21}, p_{31}$, etc.) relate to path labels in Fig. 2.

\begin{tabular}{lllllllll}
\hline Year & $p_{21}$ & $p_{31}$ & $p_{32}$ & $p_{41}$ & $p_{42}$ & $p_{43}$ & Error & $R^{2}$ \\
\hline 2005.37 & 0.06 & -0.02 & 0.27 & 0.13 & 0.09 & 0.43 & 0.76 & 0.24 \\
1991 & -0.05 & 0.15 & -0.18 & 0.17 & 0.17 & 0.42 & 0.78 & 0.22 \\
2003 & -0.06 & -0.06 & -0.01 & 0.14 & 0.11 & 0.32 & 0.87 & 0.13 \\
2005 & -0.06 & -0.06 & -0.01 & 0.09 & 0.02 & 0.39 & 0.84 & 0.16 \\
2009 & -0.06 & -0.06 & -0.01 & 0.11 & 0.25 & 0.43 & 0.75 & 0.25 \\
2011 & -0.07 & -0.06 & -0.01 & 0.13 & 0.25 & 0.38 & 0.79 & 0.21 \\
2013 & -0.07 & -0.06 & -0.01 & 0.11 & 0.24 & 0.45 & 0.74 & 0.26 \\
\hline
\end{tabular}

to shifting mosaic drivers and geomorphic catena. The blue cloud occurred predominantly below bankfull in the active channel as floodplain habitat cover types shifted across time among open channel (8), cobble (7), backwater (9), and seedlings on cobble (4). The green cloud occurred predominantly in the active floodplain catena as mature deciduous (2), immature deciduous (3), and herbaceous abandoned channels (5) cover types shifted across time. The red cloud occurred predominantly in the passive floodplain catena, with changes among mature conifer (1), immature conifer (12), herbaceous bench (6), logged areas (10), and exurban development (11) cover types. The gray arrows show transitions across the floodplain where, e.g., cut-and-fill alluviation converted mature conifer (1) to open channel (8).

\section{DISCUSSION}

Floodplains are integrative, transitional zones containing the wholly aquatic environments of the river channel and off-channel backwaters, wetlands, streams, and ponds, and the terrestrial environments of the upland shrubs, grasslands, and forests. Floodplains are subject to a suite of disturbances from both realms. Our results have revealed an example where the combination and interaction of fire and flood disturbances determine the composition and dynamics of floodplain habitats (Figs 3, 5). The floodplain shifting habitat mosaic concept recognizes the dynamics of floodplain habitats (e.g., Arscott et al. 2002, van der Nat et al. 2003, Stanford et al. 2005, Latterell et al. 2006, Whited et al. 2007, Mouw et al. 2013). However, because river hydrodynamics is an important driver of floodplain geomorphic composition, the literature on floodplain shifting habitat mosaic has been focused primarily on hydrologic and geomorphic disturbance. This focus may be, in part, a result of the limited occurrence of recent fire on various intensively studied research floodplains used to develop the floodplain shifting habitat mosaic concept (e.g., Nyack Floodplain, Montana; Tagliamento River, Italy).

We used exploratory path analyses to address the first of our 3 guiding questions. To what extent do fire, flood, and geomorphic position best explain the floodplain habitat patch composition at various points in time? Our path analysis measured the strongest effects on the variability of patch composition between reaches because we examined the relationship between environmental factors and a Bray-Curtis similarity of floodplain habitat patches throughout the valley bottom. Our path models indicate

Table 5. Direct, indirect, and total effects of explanatory factors on floodplain habitat patch composition for all sample years (sites IC-1 through IC-22), and the 2005 whole-river data set, which extends to IC-37 (2005.37).

\begin{tabular}{llrrrrrrr}
\hline Explanatory variable & Effect & 2005.37 & 1991 & 2003 & 2005 & 2009 & 2011 & 2013 \\
\hline Geomorphic composition & Indirect & -0.01 & 0.06 & -0.02 & -0.02 & -0.02 & -0.03 & -0.03 \\
& Direct & 0.13 & 0.16 & 0.14 & 0.09 & 0.10 & 0.13 & 0.11 \\
& Total & 0.12 & 0.23 & 0.12 & 0.07 & 0.08 & 0.10 & 0.08 \\
Stream power & Indirect & 0.12 & -0.08 & $<-0.01$ & -0.01 & -0.01 & -0.01 & $<-0.01$ \\
& Direct & 0.09 & 0.17 & 0.11 & 0.02 & 0.25 & 0.25 & 0.24 \\
\multirow{3}{*}{ Fire } & Total & 0.21 & 0.09 & 0.10 & 0.01 & 0.25 & 0.24 & 0.24 \\
& Indirect & 0.00 & 0.00 & 0.00 & 0.00 & 0.00 & 0.00 & 0.00 \\
& Direct & 0.43 & 0.42 & 0.32 & 0.39 & 0.43 & 0.38 & 0.45 \\
& Total & 0.43 & 0.42 & 0.32 & 0.39 & 0.43 & 0.38 & 0.45 \\
\hline
\end{tabular}




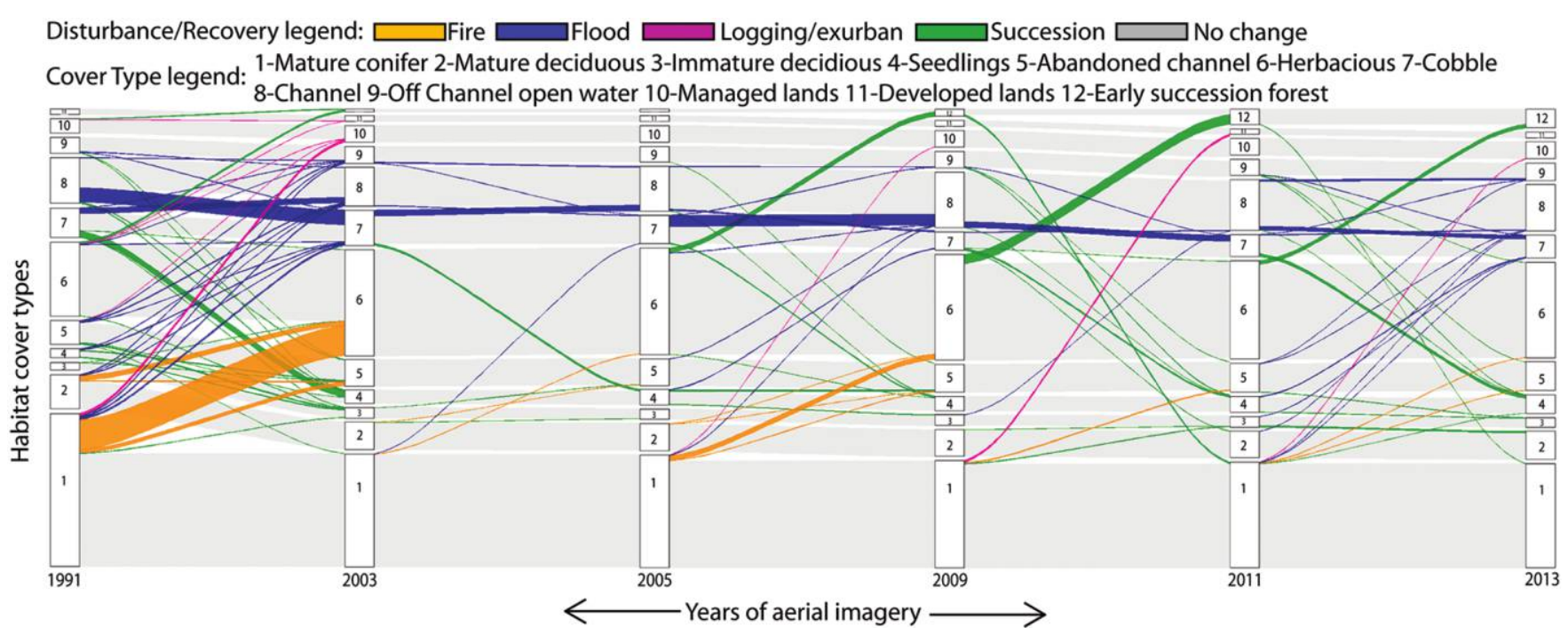

Figure 3. Alluvial graph of transitions among floodplain habitat patch composition among 6 different years of available aerial imagery.

a strong total effect of fire on the variability of floodplain habitat patch composition, that stream power and geomorphic position have a strong-to-moderate total effect on variability between reaches, and that these effects remained fairly constant across the study period (Table 5). Four large fires that involved floodplains occurred in the North Fork valley between 1988 and 2003. The alluvial graph (Fig. 3) shows the extent of habitat class transitions related to burned vegetation between 1991 and 2003, which tails off in subsequent years. However, it also shows the legacy of fire by highlighting the transitions of burned mature forest that converted to herba- ceous cover, then to immature deciduous, and back to mature forest across the $22-y$ period. The path analysis shows that fire and the subsequent recovery have a strong direct effect on the variation of floodplain habitat patches between reaches.

One cannot infer causality from path analysis (Everitt and Dunn 2001), only the magnitude of the hypothesized causal relationship between variables (Stage et al. 2004), albeit with limitations. For instance, the model shows a strong effect of fire across all years, yet it does not explain the variation in the effects of explanatory variables between years nor across the scale (e.g., 2005 whole-river
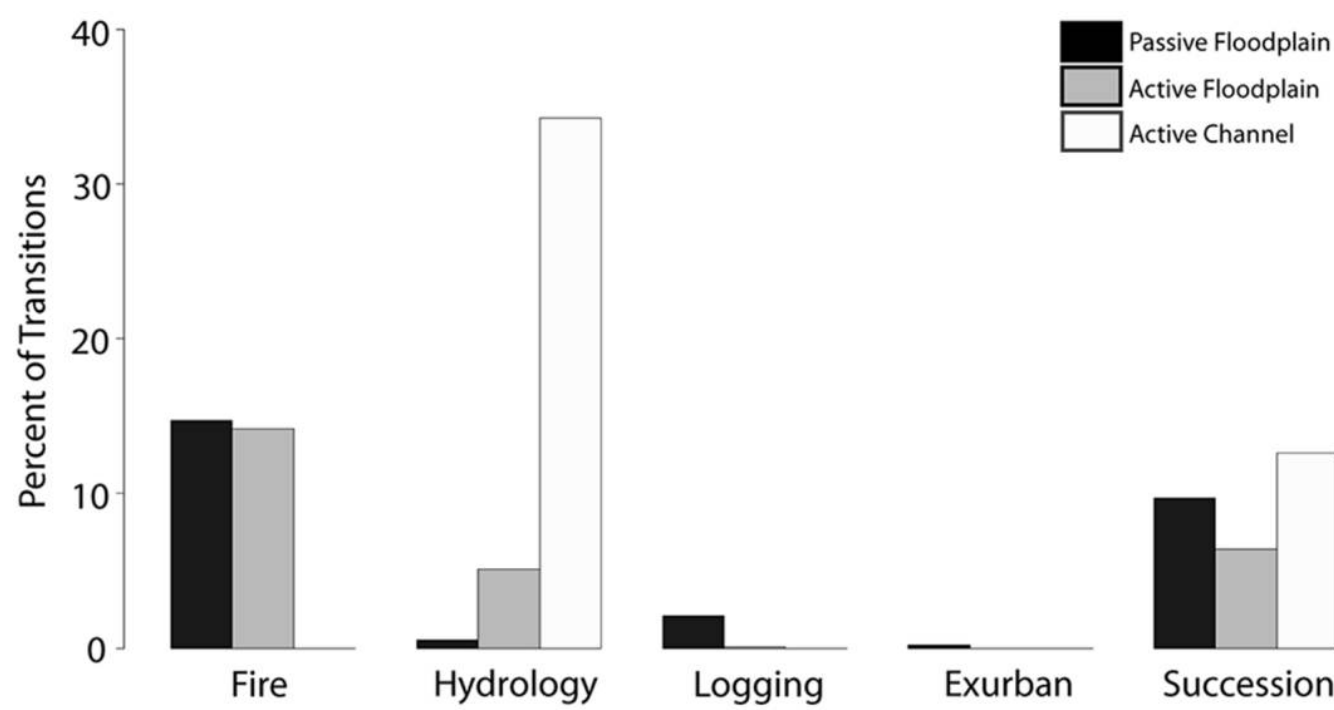

Figure 4. Percent of habitat patch transitions related to dominant disturbance/recovery vectors that occurred within each floodplain geomorphic feature across the study period. 
Table 6. Habitat cover type transitions across 22 y. Read from left to right, the table indicates the number of transitions from one cover type to another. See Table 1 for habitat cover type codes.

\begin{tabular}{|c|c|c|c|c|c|c|c|c|c|c|c|c|}
\hline \multirow[b]{2}{*}{ Habitat cover type } & \multicolumn{12}{|c|}{ Transition to: } \\
\hline & 1 & 2 & 3 & 4 & 5 & 6 & 7 & 8 & 9 & 10 & 11 & 12 \\
\hline \multicolumn{13}{|l|}{ Transition from: } \\
\hline 1 & 2879 & - & 2 & 1 & 29 & 199 & 11 & 10 & 4 & 18 & - & 3 \\
\hline 2 & - & 718 & 2 & - & 6 & 26 & 3 & 2 & 3 & - & - & - \\
\hline 3 & - & 8 & 251 & - & 3 & 1 & 1 & 1 & - & - & - & - \\
\hline 4 & - & - & 7 & 322 & 8 & - & 12 & 8 & 3 & - & - & - \\
\hline 5 & 1 & - & 9 & 1 & 684 & - & 2 & 8 & 4 & 1 & - & - \\
\hline 6 & - & - & 2 & 1 & - & 2504 & 1 & 2 & 1 & 1 & 1 & 106 \\
\hline 7 & - & - & 2 & 74 & - & 2 & 507 & 124 & 7 & - & - & - \\
\hline 8 & - & - & - & 8 & 3 & - & 136 & 1092 & 12 & - & - & - \\
\hline 9 & - & - & - & 4 & 4 & 1 & 8 & 8 & 410 & - & - & - \\
\hline 10 & - & - & - & - & - & - & - & - & - & 425 & 1 & 4 \\
\hline 11 & - & - & - & - & - & - & - & - & - & - & 148 & - \\
\hline 12 & 12 & - & - & - & - & - & - & - & - & - & - & 138 \\
\hline
\end{tabular}

data set vs 2005 data set that includes only sites below the Canadian border; Table 5). Each year's model explains a modest portion of the variance in floodplain habitat patch composition, but an unexplained variance of $0.74-$ 0.87 is present (Table 4). Therefore, other unmeasured factors not captured at the scale of this multireach assessment probably have significant effects on patch composition. These unmeasured factors could include variability in soil development, herbivory, specific as opposed to total stream power, secondary results of fire in terms of increased sediment or woody debris, and variability occurring at a finer temporal or spatial scale than captured by our study. In addition, uncertainty stemming from the data set may influence model results. Such uncertainties could include the gridded meteorological data, modeled discharge, slope from the digital elevation model, inadequate delineation of ground features, or misidentification of cover types. Furthermore, additional work is needed to inform causality within the system because we used an exploratory, rather than a confirmatory, path approach. Despite these limitations, path analysis allows us to compare the magnitude of the relationship between variables, which is 1 element that supports the plausibility of our hypothesized causal relationships. Graphical analysis provides the $2^{\text {nd }}$ element of support, and insights into the pathways of disturbance and recovery vectors in contemporary time.

Intuitively, the concept of floodplains as transition zones between aquatic and terrestrial environments reinforces the supposition that the effects of flooding or fire would have different influences on multiple structural catenae, and leads to our $2^{\text {nd }}$ question. Where did floodplain habitat patch composition change occur across the study period? The influence of flooding on habitat patch dynamics clearly reflects the floodplain aquatic-terrestrial transition, with most changes associated with flooding that occurs below bankfull, to a lesser extent in the active floodplain, and rarely in the passive floodplain (Fig. 4). Spatial shifts in floodplain habitat patches related to fire were absent in the active channel because of the lack of fuel, as one would expect. However, they were equally present on the passive and active floodplain surfaces (Fig. 4). A gradient of fire intensity from the mesic conifer communities on the passive orthofluvial floodplain to the mesic/wet communities in the active orthofluvial floodplain implies the presence of a gradient of moisture and microclimatic conditions that would enhance or deter fire. During dry periods, these moisture and microclimatic gradients decrease or are eliminated, thereby increasing potential floodplain fire intensity (Pettit and Naiman 2007). Such conditions may have been present in 1998, 2001, and 2003 to create fires that burned equally across the passive and active orthofluvial floodplain geomorphic catenae. Some uncertainty in these results can be attributed to a lack of fine-scale resolution in our mapping of the passive and active floodplain as a result of interpretations through closed canopies, intrayear image rectification, or other issues common to photogrammetry. However, $\sim 58 \%$ of the floodplain area within the perimeter of 4 fires between 1988 and 2003 was burned to some degree (MTBS 2014). We assessed the proportion of change attributed to fire among catenae, but not the mixed severity of fires within catenae. Floodplain moisture and microclimatic gradients may have existed during these fires, but 


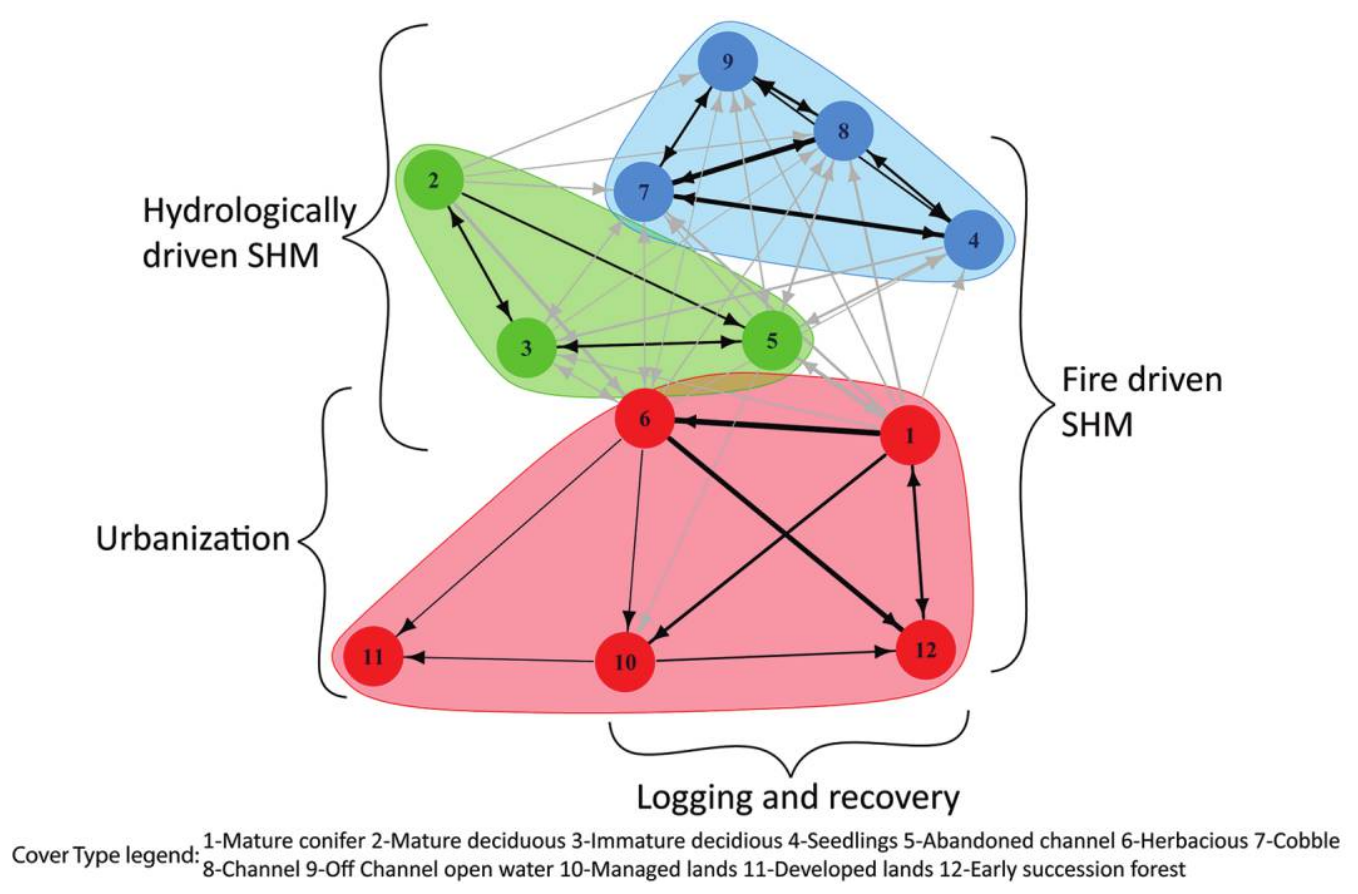

Figure 5. Network graph of habitat patch transitions of cover types 1-12 occurring collectively within sites IC-1 through IC-22 across the study period. Dense subgraphs of optimal disturbance/recovery communities, demarked by colored clouds, are derived from a random-walk algorithm (modularity 0.419). Arrows show transition direction between cover types with heaver lines indicating more transitions, black lines indicting transitions captured in the random-walk algorithm, and gray lines representing transitions among dense subgraphs. Transitions in the blue cloud occur predominantly below bankfull, in the green cloud occur predominantly in the active floodplain, and in the red cloud occur predominantly in the passive floodplain.

may have been spatially heterogeneous, laterally and longitudinally, along the floodplain and outside the scale of our reach- and catena-based measures.

Recognizing that the multivariate exploratory path analysis provides inference only on static annual events, we relied on the alluvial graph to provide insight on the dynamic aspects of our $3^{\text {rd }}$ question. What are the disturbance and recovery pathways that best describe shifts in floodplain habitat patch composition over the study period? The alluvial graph (Fig. 3) shows the important disturbance and recovery pathways in IC reaches 1 through 22 across the study period, such as fire (described above), flooding, recovery, logging, and exurban development. For instance, any point originating from, or transitioning to, the aquatic cover types river (type 8), cobble (type 7), or side-channels (type 9) was attributed to hydrologic disturbance and was colored blue. Many of the blue lines in the graph show multiple transitions between aquatic types resulting from flow pulses and occur below bankfull in the active channel as indicted in Fig. 3, whereas many smaller events where vegetated surfaces (types $1,3,4,5$, or 6) transition to aquatic cover types probably are a result of alluviation. Transitions associated with recovery via plant succession reflect processes not directly measured. Anthropogenic change was not considered significant in the path analysis because of the limited human influence on the North Fork floodplains. However, these transitions are important and were observed where mature conifer was logged (type 10) or converted to homes (type 11).

\section{Contemporary system variability}

The floodplain shifting habitat mosaic concept recognizes that the relative abundance of floodplain habitat patches remains relatively stable across ecological time scales (Arscott et al. 2002, Ward et al. 2002b, Stanford et al. 2005, Latterell et al. 2006, Whited et al. 2007). Ecological time is defined as the period necessary to establish the range-of-variation found within the floodplain habitat mosaic dynamics (Slobodkin 1961, Poff et al. 1997, Landres et al. 1999, White et al. 1999, Arscott et al. 2002). At an ecological time scale in the North Fork system, highenergy flood and flow pulses drive the physical processes of cut-and-fill alluviation, sediment deposition, and channel avulsion (Ward et al. 2002b, Hauer and Lorang 2004, Slingerland and Smith 2004, Stanford et al. 2005), which, in turn, form a patchwork of geomorphic surfaces of different physical structure and age with associated vegetation communities and varied successional states (Hauer et al. 2003, Stanford et al. 2005). These processes also cre- 
ate variable soil and fuel moisture gradients that determine fire susceptibility, intensity, and spatial and temporal dynamics (Dwire and Kauffman 2003, Pettit and Naiman 2007, Poff et al. 2011). Therefore, flood and fire interact episodically at an ecologic time scale to affect floodplain habitat patch variability in the Rocky Mountains (Dwire and Kauffman 2003, Pettit and Naiman 2007, Poff et al. 2011).

Currently, limited data truly capture the spatial and temporal components necessary to establish a range-ofvariation that defines a steady state at an ecological scale (Turner et al. 1993) for entire river systems. However, increasing access to remote-sensing products has enabled assessment of changes in disturbance and recovery dynamics within a contemporary time scale. Only a portion of the ecological time scale described above can be examined, but that portion reveals the individual mechanisms that drive aspects of the shifting habitat mosaics at large spatial scales. The alluvial graph provides a linear interpretation of contemporary change in the floodplains of the North Fork of the Flathead River over 22 y of observation. When transitions across all years are summarized in a single table (Table 6), these transitions can be viewed collectively as a network (Fig. 5) of shifting habitat elements that define contemporary system variability. The path analysis and alluvial graph can inform where different disturbance vectors can be assigned within the network that drives that variability (Figs 3,5 ).

Floodplains are among the most threatened ecosystems worldwide (Tockner and Stanford 2002). Changing disturbance dynamics associated with climate change will affect floodplain patch composition dynamics and can be counted among the many threats to floodplains, including grazing, dams, invasive species, flood control, irrigation appropriations, and urbanization (Poff et al. 2011). By examining a 60-y time series of aerial imagery, Whited et al. (2007) showed the relationship between changes in floodplain habitats of the Nyack Floodplain and annual flood magnitude associated with the cooling and warming phases of the Pacific Decadal Oscillation (PDO). The study showed that increased flooding associated with the cooling PDO phase led to extensive floodplain restructuring, whereas limited flooding associated with the PDO warming phase led to decreased flooding and a floodplain associated with later successional vegetation stages. Other investigators have found that many Rocky Mountain rivers have undergone drying trends over the last century (Rood et al. 2005), after taking the variability associated with PDO and other oceanic oscillations into account (St Jacques et al. 2010, 2013). Many rivers are predicted to have further decreases in flow over the next century (St Jacques et al. 2013), with lower snowmelt-driven peak floods that occur earlier in the spring and lower summer base flows (Rood et al. 2005, 2007), which are further com- pounded by effects of appropriations and extraction on water quantity (St Jacques et al. 2010). Collectively decreased flood peaks, earlier runoff, and lower summer flows probably will lead to overall maturation of floodplain forests with restricted cottonwood recruitment and stressed adults (Rood et al. 2008). This change probably will create xeric conditions, consequently increasing fire risk to floodplain communities. At the same time, climate change is affecting fire intensity and frequency (Dale et al. 2001, McKenzie et al. 2004), and the number of days of high fire danger are projected to increase in the future as a result of increased drying in the US Northern and Canadian Rockies (Brown et al. 2004). Ultimately, fire probably will be a dominant factor in the shifting mosaic of floodplain habitat patch composition in drier periods and flooding in the wetter periods.

The value of contemporary assessments provided by increased remote-sensing data density over the last $35 \mathrm{y}$ enabled investigators to monitor changes in floodplain ecosystem integrity, its associated functions, and related ecological services. Under the climate-driven changes described above, the flow and flood pulses of natural or perturbed flow regimes will interact with the same patch classes, albeit to a greater or lesser extent. Likewise, firedriven disturbance/recovery vectors probably would interact among the same patch classes in a fire regime that is altered by a changing climate as in one that is not. The network and alluvial graphs provide visualization of the transition communities and important drivers of the shifting habitat mosaic. The configuration of transition communities would not overtly change in future climatic scenarios unless a drastic change occurs in the system. Nevertheless, the frequencies and types of habitat class transitions that make up the underlying variability would change. Changes in networks across time is an important focus in the social sciences, and extensive analysis tools have been developed to study such changes (e.g., Kossinets and Watts 2006, Fowler et al. 2008, Steinfield et al. 2008). These new tools present opportunities to apply analytics designed to measure changes in dynamic social networks to characterize, analyze, visualize, and communicate change in the dynamics of floodplain patch networks.

\section{Broader implications}

Our study expands the floodplain shifting habitat mosaic concept by including landscape-scale disturbance that affects the composition and dynamics of the riverscape. In US Northern and Canadian Rocky Mountain rivers, fire is an important landscape-scale disturbance that drives change in floodplain habitat patch composition. A multitude of disturbance drivers that operate at the landscape and riverscape scale are important to various river systems throughout the world, and their influence on floodplain 
habitat dynamics will vary with a changing climate and land use pressures. A few examples include beetle damage (Dwire et al. 2015), beaver presence (Polvi and Wohl 2012), sediment (Macklin and Lewin 2003), invasive species (Birken and Cooper 2006), urbanization (Greene and Blossey 2014), and ice flow (Nilsson et al. 2013). The floodplain shifting habitat mosaic concept establishes a theoretical foundation for system dynamics and their drivers. Our approach is a step toward establishing elements that quantify a range of variability in a contemporary setting so that measures can be made to assess whether that variability is perturbed through climate and landuse changes.

\section{ACKNOWLEDGEMENTS}

We are very thankful to Nicolas Zegre of West Virginia University for his initial assistance with the HBV-EC hydrologic model code and to Wayne Jenkinson of the Canadian Hydraulics Centre for providing a contemporary copy of the HBV-EC hydrologic model executable. We also thank Ryan Jones and David Roberts of Montana State University for their assistance in Mantel and graphical analysis and Guest Editor Robert E. Gresswell of the US Geological Service for his insights on fire. Senior author WJK was supported in part by the National Science Foundation EPSCoR program under Grant NSF-IIA-1443108 and by the Flathead Lake Biological Station's Limnology Professorship of FRH. Any opinions, findings, and conclusions or recommendations expressed in this material are those of the author(s) and do not necessarily reflect the views of the National Science Foundation.

\section{LITERATURE CITED}

Allan, J. D. 2004. Landscapes and riverscapes: the influence of land use on stream ecosystems. Annual Review of Ecologv, Evolution, and Svstematics 35:257-284.

Arno, S. F. 1980. Forest fire history in the Northern Rockies. Journal of Forestry 78:460-465.

Arno, S. F., D. J. Parsons, R. E. Keane. 2000. Mixed-severity fire regimes in the northern Rocky Mountains: consequences of fire exclusion and options for the future. Pages 225-232 in D. N. Cole, S. F. McCool, W. T. Borrie, and J. O'Loughlin (editors). Wilderness Science in a Time of Change: a Conference. Volume 5: Wilderness ecosystems, threats, and management. 1999 May 23-27; Missoula, MT. Proceedings RMRS-P-15-VOL-5. Rocky Mountain Research Station, US Department of Agriculture Forest Service, Ogden, Utah. (Available from: http://www.wilderness.net/library/documents/Arno _5-26.pdf)

Arscott, D. B., K. Tockner, D. van der Nat, and J. V. Ward. 2002. Aquatic habitat dynamics along a braided alpine river ecosystem (Tagliamento River, Northeast Italy). Ecosystems 5:802-814.

Birken, A. S., and D. J. Cooper. 2006. Processes of Tamarix invasion and floodplain development along the lower Green River, Utah. Ecological Applications 16:1103-1120.

Bormann, F. H., and G. E. Likens. 1979. Pattern and process in a forested ecosystem. Springer-Verlag, New York.
Brown, T. J., B. L. Hall, and A. L. Westerling. 2004. The impact of twenty-first century climate change on wildland fire danger in the western United States: an applications perspective. Climatic Change 62:365-388.

Brunke, M., E. Hoehn, and T. Gonser. 2003. Patchiness of rivergroundwater interactions within two floodplain landscapes and diversity of aquatic invertebrate communities. Ecosystems 6:707-722.

Bull, W. B. 1979. Threshold of critical power in streams. Geological Societv of America Bulletin 90:453-464.

Camporeale, C., E. Perucca, L. Ridolfi, and A. M. Gurnell. 2013. Modeling the interactions between river morphodynamics and riparian vegetation. Reviews of Geophysics 51:379-414.

Canadian Hydraulics Centre. 2010. Green Kenue reference manual. National Research Council, Ottawa, Canada. (Available from: http://www.nrc-cnrc.gc.ca/eng/solutions/advisory /green_kenue_index.html)

Castillo-Monroy, A. P., M. A. Bowker, F. T. Maestre, S. Rodríguez-Echeverría, I. Martinez, C. E. Barraza-Zepeda, and C. Escolar. 2011. Relationships between biological soil crusts, bacterial diversity and abundance, and ecosystem functioning: insights from a semi-arid Mediterranean environment. Iournal of Vegetation Science 22:165-174.

Cooper, H. H., and M. I. Rorabaugh. 1963. Ground-water movements and bank storage due to flood stages in surface streams. U.S. Geological Survey Supply Paper 1536-J:343-363.

Dale, V. H., L. A. Joyce, S. McNulty, R. P. Neilson, M. P. Ayres, M. D. Flannigan, P. J. Hanson, L. C. Irland, A. E. Lugo, C. J. Peterson, D. Simberloff, F. J. Swanson, B. J. Stocks, and B. M. Wotton. 2001. Climate change and forest disturbances: climate change can affect forests by altering the frequency, intensity, duration, and timing of fire, drought, introduced species, insect and pathogen outbreaks, hurricanes, windstorms, ice storms, or landslides. BioScience 51:723-734.

DataBC. 2014. British Columbia spatial data: fire history. GeoBC. Providence of British Columbia, Victoria, British Columbia. (Available from: http://www.data.gov.bc.ca/dbc/geographic/index.page)

Dwire, K. A., R. Hubbard, and R. Bazan. 2015. Comparison of riparian and upland forest stand structure and fuel loads in beetle infested watersheds, southern Rocky Mountains. Forest Ecology and Management 335:194-206.

Dwire, K. A., and J. B. Kauffman. 2003. Fire and riparian ecosystems in landscapes of the western USA. Forest Ecology and Management 178:61-74.

Environment Canada. 2013. Historic Hydrologic Data: British Columbia gauge station number. 08NP001. Environmental Canada Water Office. Fredericton, New Brunswick. (Available from: http://wateroffice.ec.gc.ca/report/report_e.html?type $=\mathrm{h} 2 \mathrm{oArc} \& \operatorname{stn}=08 \mathrm{NP001 \# )}$

Everitt, B. S., and G. Dunn. 2001. Applied multivariate data analysis. Edward Arnold Ltd, London, UK.

Fowler, J. H., and N. A. Christakis. 2008. Dynamic spread of happiness in a large social network: longitudinal analysis over 20 years in the Framingham heart study. British Medical Journal 337:1-9.

Fox, J., Z. Nie, J. Byrnes, and M. Culbertson. 2013. SEM: structural equation models. R-manual. R Project for Statistical Computing, Vienna, Austria. (Available from: http://CRAN.R -project.org $/$ package $=$ sem) 
Google Earth. 2013. Flathead River system $48^{\circ} 30^{\prime} 00.39^{\prime \prime} \mathrm{N}, 114^{\circ} 0^{\prime}$ 01.67"W, elevation 1000M. Imagery Date 4/9/13. Version 7.1.4. Google Inc., Mountain View, California. (Available from: www .google.com/earth/)

Grace, J. B. 2006. Structural equation modeling and natural systems. Cambridge University Press, Cambridge, UK.

Grace, J. B., T. M. Anderson, H. Olff, and S. M. Scheiner. 2010. On the specification of structural equation models for ecological systems. Ecological Monographs 80:67-87.

Greene, B., and B. Blossey. 2014. Patterns of privet: urbanizing watersheds, invasive Ligustrum sinense, and performance of native plant species in Piedmont floodplain forests. Ecosystems 17:990-1001.

Gurnell, A. 2014. Plants as river system engineers. Earth Surface Processes and Landforms 39:4-25.

Hauer, F. R., B. J. Cook, M. C. Gilbert, E. J. Clairain, and R. D. Smith. 2002. A regional guidebook for applying the hydrogeomorphic approach to assessing wetland functions of riverine floodplains in the northern Rocky Mountains. US Army Engineer Research and Development Center, Vicksburg, Mississippi.

Hauer, F. R., C. N. Dahm, G. A. Lamberti, and J. A. Stanford. 2003. Landscapes and ecological variability of rivers in North America: factors affecting restoration strategies. Pages 81105 in R. C. Wissmar and P. A. Bisson (editors). Strategies for restoring river ecosystems: sources of variability and uncertainty in natural and managed systems. American Fisheries Society, Bethesda, Maryland.

Hauer, F. R., and M. S. Lorang. 2004. River regulation, decline of ecological resources, and potential for restoration in a semi-arid lands river in the western USA. Aquatic Sciences 66:388-401.

Hughes, D. A. 1980. Floodplain inundation: processes and relationships with channel discharge. Earth Surface Processes 5: 297-304.

Intaraprasong, T., and H. Zhan. 2009. A general framework of stream-aquifer interaction caused by variable stream stages. Journal of Hydrology 373:112-121.

Jackson, B. K., and S. M. P. Sullivan. 2009. Influence of wildfire severity on riparian plant community heterogeneity in an Idaho, USA wilderness. Forest Ecology and Management 259:24-32.

Jost, G., R. D. Moore, B. Menounos, and R. Wheate. 2012. Quantifying the contribution of glacier runoff to streamflow in the upper Columbia River Basin, Canada. Hydrology and Earth System Sciences 16:849-860.

Junk, W. J., P. B. Bayley, and R. E. Sparks. 1989. The flood pulse concept in river-floodplain systems. Canadian Special Publication of Fisheries and Aquatic Sciences 106:110-127.

Keane, R. E., K. C. Ryan, T. T. Veblen, C. D. Allen, J. A. Logan, and B. Hawkes. 2002. The cascading effects of fire exclusion in Rocky Mountain ecosystems: a literature review. General Technical Report RMRS-GTR-9. US Department of Agriculture Forest Service, Rocky Mountain Station, Fort Collins, Colorado.

Kincaid, T. M., and A. R. Olsen. 2013. Spsurvey: spatial survey design and analysis. R-Manual. R Project for Statistical Computing, Vienna, Austria. (Available from: http://www.epa.gov /nheerl/arm/)
Kossinets, G., and D. J. Watts. 2006. Empirical analysis of an evolving social network. Science 311:88-90.

Landres, P. B., P. Morgan, and F. J. Swanson. 1999. Overview of the use of natural variability concepts in managing ecological systems. Ecological Applications 9:1179-1188.

Latterell, J. J., J. S. Bechtold, T. C. O'Keefe, R. van Pelt, and R. J. Naiman. 2006. Dynamic patch mosaics and channel movement in an unconfined river valley of the Olympic Mountains. Freshwater Biology 51:523-544.

Legendre, P., and L. F. Legendre. 2012. Numerical ecology. $3^{\text {rd }}$ edition. Elsevier, Amsterdam, The Netherlands.

Lewin, J., and D. Hughes. 1980. Welsh floodplain studies: II. Application of a qualitative inundation model. Journal of $\mathrm{Hy}-$ drology 46:35-49.

Lorang, M. S., and F. R. Hauer. 2003. Flow competence and streambed stability: an evaluation of technique and application. Journal of the North American Benthological Society 22:475-491.

Lorang, M. S., and F. R. Hauer. 2006. Fluvial geomorphic processes. Pages 145-168 in F. R. Hauer and G. A. Lamberti (editors). Methods in stream ecology. $2^{\text {nd }}$ edition. Elsevier, San Diego, California.

Macklin, M. G., and J. Lewin. 2003. River sediments, great floods and centennial-scale Holocene climate change. Journal of Ouaternarv Science 18:101-105.

Mahat, V., and A. Anderson. 2013. Impacts of climate and catastrophic forest changes on streamflow and water balance in a mountainous headwater stream in Southern Alberta. $\mathrm{Hy}-$ drology and Earth System Sciences 17:4941-4956.

Mantel, N. 1967. The detection of disease clustering and a generalized regression approach. Cancer Research 27:209220.

McGlynn, B. L., and J. J. McDonnell. 2003. Quantifying the relative contributions of riparian and hillslope zones to catchment runoff. Water Resources Research 39:1310-1330.

McKenzie, D., Z. Gedalof, D. L. Peterson, and P. Mote. 2004. Climatic change, wildfire, and conservation. Conservation Biology 18:890-902.

Mertes, L. A. K. 1997. Documentation and significance of the perirheic zone on inundated floodplains. Water Resources Research 33:1749-1762.

Miall, A. D. 1985. Architectural-element analysis: a new method of facies analysis applied to fluvial deposits. Earth-Science Reviews 22:261-308.

Miller, R. G. 1966. Simultaneous statistical inference. Springer, New York.

Mouw, J. E. B., J. L. Chaffin, D. C. Whited, F. R. Hauer, P. L. Matson, and J. A. Stanford. 2013. Recruitment and successional dynamics diversify the shifting habitat mosaic of an Alaskan floodplain. River Research and Applications 29:671685.

Mouw, J. E. B., J. A. Stanford, and P. B. Alaback. 2009. Influences of flooding and hyporheic exchange on floodplain plant richness and productivity. River Research and Applications 25:929-945.

MTBS (Monitoring Trends in Burn Severity). 2014. Monitoring trends in burn severity. Remote Sensing Applications Center, Salt Lake City, Utah. (Available from: http://www.mtbs .gov/index.html) 
Naiman, R. J., and H. Décamps. 1997. The ecology of interfaces: riparian zones. Annual Review of Ecology and Systematics 28:621-658.

Naiman, R. J., H. Décamps, and M. Pollock. 1993. The role of riparian corridors in maintaining regional biodiversity. Ecological Applications 3:209-212.

Nash, J. E., and J. V. Sutcliffe. 1970. River flow forecasting through conceptual models part I-A discussion of principles. Journal of Hydrology 10:282-290.

Natel, P., and P. Neumann. 1992. Ecology of ectomycorrhizalbasidiomycete communities on a local vegetation gradient. Ecology 73:99-117.

Nilsson, C., R. Jansson, L. Kuglerová, L. Lind, and L. Ström. 2013. Boreal riparian vegetation under climate change. Ecosystems 16:401-410.

Oksanen, J., F. G. Blanchet, R. Kindt, P. Legendre, P. R. Minchin, R. B. O'Hara, G. L. Simpson, P. Solymos, M. H. H. Stevens, and H. Wagner. 2013. vegan: community ecology package. R-manual. R Project for Statistical Computing, Vienna, Austria. (Available from: http://CRAN.R-project.org /package $=$ vegan $)$

Omang, R. J. 1992. Analysis of the magnitude and frequency of floods and the peak-flow gaging network in Montana. Water-Resources Investigations Report 92-4048. US Geological Survey, Helena, Montana.

Perry, D. A., P. F. Hessburg, C. N. Skinner, T. A. Spies, S. L. Stephens, A. H. Taylor, J. F. Franklin, B. McComb, and G. Riegel. 2011. The ecology of mixed severity fire regimes in Washington, Oregon, and Northern California. Forest Ecologv and Management 262:703-717.

Pettit, N. E., and R. J. Naiman. 2007. Fire in the riparian zone: characteristics and ecological consequences. Ecosystems 10: 673-687.

Poff, B., K. A. Koestner, D. G. Neary, and V. Henderson. 2011. Threats to riparian ecosystems in Western North America: an analysis of existing literature. Iournal of the American Water Resources Association 47:1241-1254.

Poff, N. L., J. D. Allan, M. B. Bain, J. R. Karr, K. L. Prestegaard, B. D. Richter, R. E. Sparks, and J. C. Stromberg. 1997. The natural flow regime. A paradigm for river conservation and restoration. BioScience 47:769-784.

Polvi, L. E., and E. Wohl. 2012. The beaver meadow complex revisited-the role of beavers in post-glacial floodplain development. Earth Surface Processes and Landforms 37:332346.

Pons, P., and M. Latapy. 2005. Computing communities in large networks using random walks. Computer and Information Sciences-ISCIS 2005 3733:284-293.

Rollins, M. G., P. Morgan, and T. Swetnam. 2002. Landscapescale controls over 20th century fire occurrence in two large Rocky Mountain (USA) wilderness areas. Landscape Ecology 17:539-557.

Rood, S. B., G. M. Samuelson, J. K. Weber, and K. A. Wywrot. 2005. Twentieth-century decline in streamflows from the hydrographic apex of North America. Iournal of Hydrology 306:215-233.

Rood, S. B., J. Pan, K. M. Gill, C. G. Franks, G. M. Samuelson, and A. Shepherd. 2008. Declining summer flows of Rocky Mountain rivers: changing seasonal hydrology and probable impacts on floodplain forests. Journal of Hydrology 349:397410.

Rood, S. B., L. A. Goater, J. M. Mahoney, C. M. Pearce, and D. G. Smith. 2007. Floods, fire, and ice: disturbance ecology of riparian cottonwoods. Canadian Journal of Botany 85:10191032.

Schoennagel, T., T. T. Veblen, and W. H. Romme. 2004. The interaction of fire, fuels, and climate across Rocky Mountain forests. BioScience 54:661-676.

Slingerland, R., and N. D. Smith. 2004. River avulsions and their deposits. Annual Review of Earth and Planetary Sciences 32:257-285.

Slobodkin, L. B. 1961. Growth and regulation of animal populations. Holt, Rinehart and Winston, New York.

Smouse, P. E., J. C. Long, and R. R. Sokal. 1986. Multiple regression and correlation extensions of the Mantel test of matrix correspondence. Systematic Zoology 35:627-632.

Sokal, R. R., and F. J. Rohlf. 1995. Biometry: the principles and practice of statistics in biological research. $3^{\text {rd }}$ edition. W. $\mathrm{H}$. Freeman, New York.

St Jacques, J. M., S. L. Lapp, Y. Zhao, E. M. Barrow, and D. J. Sauchyn. 2013. Twenty-first century central Rocky Mountain river discharge scenarios under greenhouse forcing. Quaternary International 310:34-46.

St Jacques, J. M., D. J. Sauchyn, and Y. Zhao. 2010. Northern Rocky Mountain streamflow records: global warming trends, human impacts or natural variability? Geophysical Research Letters 37:5.

Stage, F. K., H. C. Carter, and A. Nora. 2004. Path analysis: an introduction and analysis of a decade of research. Journal of Educational Research 98:5-13.

Stanford, J. A., M. S. Lorang, and F. R. Hauer. 2005. The shifting habitat mosaic of river ecosystems. Verhandlungen der Internationalen Vereinigung für theoretische und angewandte Limnologie 29:123-136.

Steinfield, C., N. B. Ellison, and C. Lampe. 2008. Social capital, self-esteem, and use of online social network sites: a longitudinal analysis. Iournal of Applied Developmental Psychology 29:434-445.

Strohbach, M., V. Audorff, and C. Beierkuhnlein. 2009. Drivers of plant species composition in siliceous spring ecosystems: groundwater chemistry, catchment traits or spatial factors? Journal of Limnology 68:375-384.

Thornton, P. E., M. M. Thornton, B. W. Mayer, N. Wilhelmi, Y. Wei, and R. B. Cook. 2012. Daymet: daily surface weather on a 1-km grid for North America, 1980-2012. Oak Ridge National Laboratory Distributed Active Archive Center, Oak Ridge, Tennessee. (Available from: http://daymet.ornl.gov /daymet_doi)

Tockner, K., F. Malard, and J. V. Ward. 2000. An extension of the flood pulse concept. Hydrological Processes 14:2861-2883.

Tockner, K., M. Pusch, D. Borchardt, and M. S. Lorang. 2010. Multiple stressors in coupled river-floodplain ecosystems. Freshwater Biology 55:135-151.

Tockner, K., and J. A. Stanford. 2002. Riverine flood plains: present state and future trends. Environmental Conservation 29:308-330.

Turner, M. G., and W. H. Romme. 1994. Landscape dynamics in crown fire ecosystems. Landscape Ecology 9:59-77. 
Turner, M. G., W. H. Romme, R. H. Gardner, R. V. O'Neill, and T. K. Kratz. 1993. A revised concept of landscape equilibrium: disturbance and stability on scaled landscapes. Landscape Ecology 8:213-227.

USGS (US Geological Survey). 2013. Digital elevation map: seamless data. US Geological Survey, Reston, Virginia. (Available from: http://nationalmap.gov/viewer.html)

USGS (US Geological Survey). 2014. The national map viewer. (Available from: http://nationalmap.gov/viewer.html)

van der Nat, D., K. Tockner, P. J. Edwards, J. V. Ward, and A. M. Gurnell. 2003. Habitat change in braided flood plains (Tagliamento, NE-Italy). Freshwater Biology 48:1799-1812.

Wagener, T., M. J. Lees, and H. S. Wheater. 2001. Monte-Carlo analysis toolbox user manual. Department of Civil and Environmental Engineering, Imperial College London, London, UK.

Ward, J. V. 1998. Riverine landscapes: biodiversity patterns, disturbance regimes, and aquatic conservation. Biological Conservation 83:269-278.

Ward, J. V., F. Malard, and K. Tockner. 2002a. Landscape ecology: a framework for integrating pattern and process in river corridors. Landscape Ecology 17:35-45.
Ward, J. V., K. Tockner, D. B. Arscott, and C. Claret. 2002b. Riverine landscape diversity. Freshwater Biology 47:517539.

White, P. S., J. Harrod, W. H. Romme, and J. Betancourt. 1999. Disturbance and temporal dynamics. Pages 281-305 in N. C. Johnson, A. J. Malk, W. T. Sexton, and R. Szaro (editors). Ecological stewardship: a common reference for ecosystem management. Oxford, University, Oxford, UK.

Whited, D. C., M. S. Lorang, M. J. Harner, F. R. Hauer, J. S. Kimball, and J. A. Stanford. 2007. Climate, hydrologic disturbance, and succession: drivers of floodplain pattern. Ecology 88:940-953.

Wiens, J. A. 2002. Riverine landscapes: taking landscape ecology into the water. Freshwater Biology 47:501-515.

WRCC (Western Regional Climate Center). 2013. Hungry Horse evaporation summary. Western Regional Climate Center, Reno, Nevada. (Available from: http://www.wrcc.dri.edu /htmlfiles/westevap.final.html)

WRCC (Western Regional Climate Center). 2014. Polebridge, MT climate summary. Western Regional Climate Center, Reno, Nevada. (Available from: http://www.wrcc.dri.edu/cgi-bin /cliMAIN.pl?mt6615) 